\title{
Commitment, attitude and behavioural changes of the community towards a waste segregation program: a case study of Malaysia
}

\author{
S. I. Sharifah Norkhadijah, H. Hajar Mariah, \\ R. Irniza \& Z. A. Emilia \\ Department of Environmental and Occupational Health, \\ Universiti Putra Malaysia, Malaysia
}

\begin{abstract}
The rate of waste segregation is poor in Malaysia where only $5 \%$ of waste is segregated and recycled. This cross-sectional study was conducted at Taman Sri Andalas, Serdang Jaya Selangor to determine factors that are associated with the participation of the public in a waste segregation program and to determine the reduction of waste from the waste segregation activity implemented in this study. A total of 69 households were arbitrarily selected across streets to participate in this study. Two types of bins (i.e. recycled and food waste) were provided to each participating household and the weights of the waste were measured at two different time intervals. The behavioural changes of respondents were assessed based on the Theory of Planned Behaviour. The volume of waste segregated has increased significantly, from $9.4 \%$ to $10.6 \%$ while $13.3 \%$ of the community waste is food waste that could be used as compost. In total, the volume of waste designated for the landfill has decreased from $100 \%$ to $76.2 \%$ in the span of three weeks. Nine behavioural factors show significant positive changes between the start and the end of the program. The waste segregation program that was conducted has resulted in behavioural changes of households towards waste segregation activity.
\end{abstract}

Keywords: commitment, attitude, behavioural change, waste segregation program, Malaysia.

\section{Introduction}

Waste management is currently one of the significant concerns in public health. Increased population growth has resulted in increased waste generation [1]. The changes of lifestyle and living standard of households are factors that contribute 
to the increase of waste [2]. Table 1 presents the volume of municipal solid waste (MSW) generated in peninsular Malaysia from 1970 to 2010.

In the present-day, Malaysia generates up to 17,000 tonnes of waste per day and by 2020 the waste is expected to increase to 30,000 tonnes per day [3]. The government has been putting efforts to reduce the amount of waste designated for disposals in landfills as many of the existing landfills have reached their maximum capacity and need to stop operating. Segregation of organic and food waste from recyclable materials is expected to reduce the volume of waste for landfill disposal and will increase the rate of recycling [2]. With a target to increase the recycling rate to $22 \%$ by 2020 in Malaysia, a waste segregation program has been increasingly implemented to promote recycling but the current recycling rate is largely low. The presence of a large number of landfills is a major concern in the country. Most of the landfills in Malaysia are non-sanitary and are devoid of proper engineering control to protect the environment from pollution such as leachates [1]. For example, in 2009, there were 176 landfills with an improper management status in Malaysia and only $10 \%$ of them were sanitary landfill (Table 2). However, as landfills are the most practical and lowcost method of waste disposal, the use of landfills still continues. Therefore, waste segregation can be one of the best alternatives to help in reducing the volume of waste for landfill disposal and in the long-term to protect the environment.

While the government has a policy on effective waste management and has introduced awareness programs focusing on waste recycling, there is still an obvious gap in the actual practice. For example, recycling infrastructure has not been made easily available in communities except for a select few. This might likely be the reason, which limits the willingness of the public to attempt

Table 1: Generation of MSW in peninsular Malaysia (1970-2010) [2].

\begin{tabular}{llllllll}
\hline Urban center & \multicolumn{7}{l}{ Solid waste generated (tonnes / day) } \\
\cline { 2 - 8 } & $\mathbf{1 9 7 0}$ & $\mathbf{1 9 8 0}$ & $\mathbf{1 9 9 0}$ & $\mathbf{2 0 0 2}$ & $\mathbf{2 0 0 6}$ & $\mathbf{2 0 0 9}$ & $\mathbf{2 0 1 0}$ \\
\hline Kuala Lumpur & 98.9 & 310.5 & 586.8 & 2754 & 3100 & 3387 & 3489 \\
Johor Bahru & 41.1 & 99.6 & 174.8 & & & & \\
& & & & & & & \\
Ipoh, Perak & 22.5 & 82.7 & 162.2 & 208 & 234 & 256 & 264 \\
Georgetown, Penang & 53.4 & 83.0 & 137.2 & 221 & 249 & 272 & 280 \\
Klang, Selangor & 18.0 & 65.0 & 122.8 & 478 & 538 & 588 & 606 \\
K.Terengganu & 8.7 & 61.8 & 121.0 & 137 & 154 & 168 & 173 \\
K.Bharu, Kelantan & 9.1 & 56.5 & 102.9 & 129.5 & 146 & 160 & 165 \\
Kuantan, Pahang & 7.1 & 45.2 & 85.3 & 174 & 196 & 214 & 220 \\
Seremban, N.sembilan & 13.4 & 45.1 & 85.2 & 165 & 186 & 203 & 209 \\
Melaka & 14.4 & 29.1 & 46.8 & 562 & 632 & 691 & 712 \\
\hline
\end{tabular}


recycling [2], apart from the lack of awareness or knowledge on the part of the community. The Theory of Planned Behaviour (TPB) suggests a theoretical frame-work for systematically determining the potential factors that influence recycling participation amongst the public [5]. This theory has been used by several studies as a basis to examine human behaviour towards recycling [6-8]. Available literature has addressed recycling behaviour using this theory to assess the changes of behaviour to recycling [7,9]. Given the issues regarding recycling, this study aimed to determine the commitment, attitude and behavioural change of the community towards waste segregation practices through the implementation of a supported program.

Table 2: Landfills status in Malaysia [4].

\begin{tabular}{lccc}
\hline \multicolumn{1}{c}{ State } & Operating & End of life & Sanitary \\
\hline Perlis & 1 & 1 & 0 \\
Kedah & 10 & 5 & 0 \\
Penang & 1 & 2 & 0 \\
Perak & 20 & 9 & 0 \\
Pahang & 19 & 13 & 1 \\
Selangor & 6 & 12 & 3 \\
Putrajaya & 0 & 0 & 0 \\
Kuala Lumpur & 1 & 7 & 1 \\
N. Sembilan & 8 & 10 & 0 \\
Malacca & 2 & 5 & 0 \\
Johor & 13 & 21 & 1 \\
Kelantan & 13 & 4 & 0 \\
& & & \\
Terengganu & & 12 & 0 \\
Labuan & 9 & 0 & 0 \\
Sabah & 1 & 1 & 0 \\
Sarawak & 21 & 12 & 3 \\
Total & 51 & $\mathbf{1 1 4}$ & $\mathbf{8}$ \\
\hline
\end{tabular}

\section{Materials and methods}

\subsection{Data collection}

\subsubsection{Site description}

A cross-sectional study was conducted in Taman Sri Andalas, Serdang Jaya Selangor (Fig. 1). A total of 69 respondents have participated in this program. The community of Serdang Jaya was selected as they have no waste segregation program at present. The location of this study has a waste collection scheduled and nearly $100 \%$ of their waste was collected by the local authority. Thus, we can measure the total waste that was disposed by each household before it was collected by the waste collector. 


\subsubsection{Sampling method}

Simple random sampling was applied in this study. The randomization was performed across different streets rather than at the individual household level. This is because of the expectation that recycling behaviour is influenced by subjective norms (individual's perception of social pressure to recycle household waste). If they see their neighbours living across the same street recycle their waste, then they will likely be influenced by that behaviour [10]. Streets that were involved in this study were Jalan Raya Lima, Jalan 4/4, Jalan 4/1, Jalan 4/2 (Lorong 4/2A, 4/2B, 4/2C) and Jalan 4/3 (Lorong 4/3A, 4/2C, 4/3C) (Figure 1).

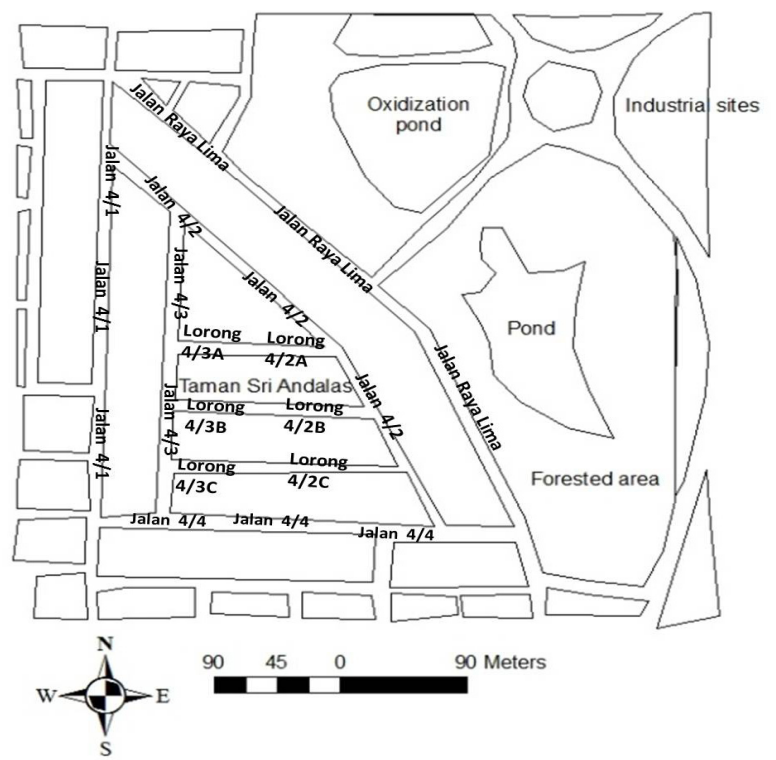

Figure 1: Study area.

\subsubsection{Waste segregation program}

A waste segregation program was conducted for a period of three weeks, in 3 phases. In the first phase, waste segregation activity in the study area was monitored, and a set of questionnaires were distributed to members of the households to assess the required information. In the second phase of this study, a recycling bin was provided for every household and they were given information on how to segregate waste specific to this recycle bin. A set of questionnaires was then distributed to assess the behavioural changes after the provision of the bin. In the third phase, a food waste bin was provided along with the information on how to segregate waste specific to this bin. A questionnaire was again used to assess their behaviour at the end of the program. Waste that was segregated by the household each week was weighed and summed up to obtain the total amount of waste segregated. Figure 2 illustrates the flow of data collection in this study. 


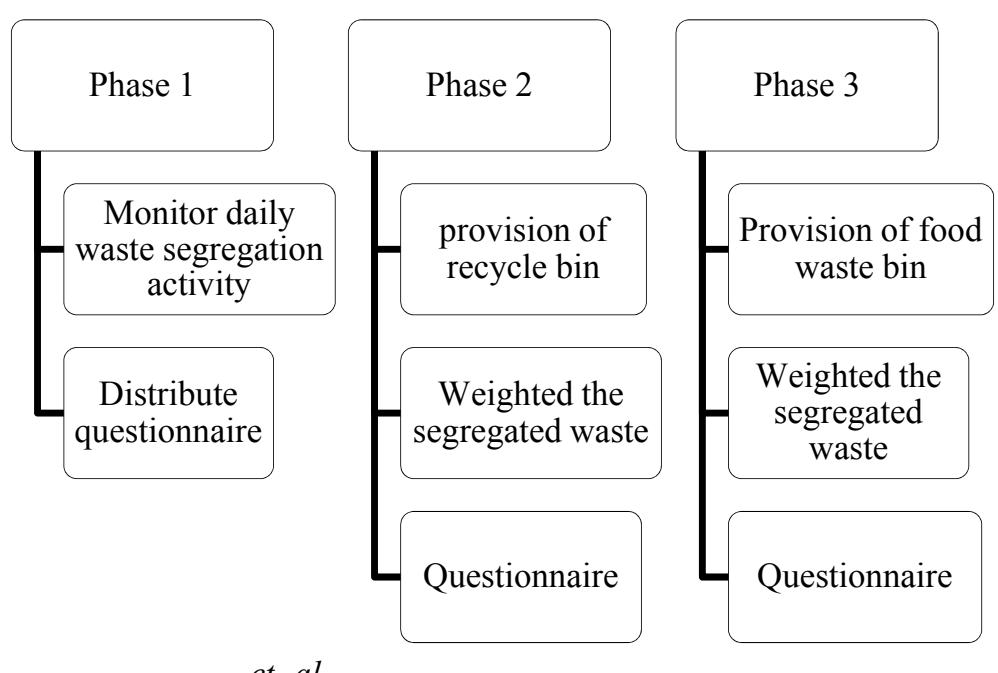

Figure 2: $\quad \begin{gathered}e t \\ e t a l\end{gathered}$

\subsubsection{Questionnaire}

There were eight components of variables in the questionnaire: (1) attitudes; (2) subjective norms; (3) perceived behavioural controls; (4) situational factors;

(5) outcome factors; (6) consequences factors; (7) perceived lack of facility; (8) and moral norms. These eight components were assessed via Likert-scale responses. The scale is defined as: strongly disagrees $=1$; disagree $=2$; not sure $=3$; agree $=4$; and strongly agree $=5$. Table 3 lists and defines variables that were assessed in the study questionnaire.

\section{Results and discussion}

\subsection{Socio-demographic information of respondents}

More than half of the respondents were between the ages of 56-65 years old $(58 \%)$, males $(64 \%)$, married $(88.4 \%)$ and were of Malay ethnicity $(94.2 \%)$. The number of people per households was between 4 to 7 (65\%). The highest level of education for most of the respondents was secondary school level (53.6\%). The range of family income for most families was between RM 2001 to RM 3000 $(24.6 \%)$. Most of the breadwinners took a pension scheme.

\subsection{Waste segregated by the households}

For the duration of the three week program, 3,117.4 kg of waste was generated. In average (mean \pm standard deviation) $45.18 \pm 15.43 \mathrm{~kg}$ of waste were generated per week and $2.15 \pm 0.73 \mathrm{~kg}$ per day per household. From the total of $1,097.7 \mathrm{~kg}$ waste generated in phase $3,10.58 \%(115.6 \mathrm{~kg})$ of the waste were recycled. This volume has increased from $9.39 \%(98.6 \mathrm{~kg})$ in phase 2. Almost $13.26 \%(144.9 \mathrm{~kg})$ of waste in phase 3 was food waste (Table 4). 
Table 3: Definition of eight components of variables.

\begin{tabular}{|c|c|c|}
\hline & Variable & Definitions \\
\hline Attitude & $\begin{array}{l}\text { PLEASING } \\
\text { INTEREST } \\
\text { POSITIVE } \\
\text { UNPLEASNT } \\
\text { FAVOR }\end{array}$ & $\begin{array}{l}\text { Idea of waste segregation is pleasing. } \\
\text { Interest of household to segregated waste. } \\
\text { Positive feeling to segregated waste } \\
\text { Segregated waste is unpleasant } \\
\text { Favourable feelings to segregated waste }\end{array}$ \\
\hline Subjective norms & $\begin{array}{l}\text { FRIEND } \\
\text { FAMILY } \\
\text { NEIGHB } \\
\text { IMPTPEO } \\
\text { ACQUAIN } \\
\end{array}$ & $\begin{array}{l}\text { Friends influence to segregate waste } \\
\text { Family influence to segregate waste } \\
\text { Neighbours influence to segregate waste } \\
\text { Important people influence to segregate waste } \\
\text { Acquaintance influence to segregate waste }\end{array}$ \\
\hline $\begin{array}{l}\text { Perceived } \\
\text { behaviour }\end{array}$ & $\begin{array}{l}\text { EASY } \\
\text { COUNCIL } \\
\text { OPPORT } \\
\text { RECITEMS } \\
\text { RECCENTRE } \\
\text { SEGREGATE }\end{array}$ & $\begin{array}{l}\text { Perception of recycling is easy } \\
\text { Perception of local council provide satisfactory } \\
\text { facilities } \\
\text { Available opportunities to segregate waste } \\
\text { Knowledge on recycle item } \\
\text { Knowledge on recycling center locations } \\
\text { Knowledge to segregate waste }\end{array}$ \\
\hline Situational factors & $\begin{array}{l}\text { TIME } \\
\text { ROOM } \\
\text { COMPLI } \\
\text { WSMONEY } \\
\text { FAR }\end{array}$ & $\begin{array}{l}\text { Belief that waste segregation time consuming } \\
\text { Belief that waste segregation take up too much room } \\
\text { Belief that waste segregation considered complicated } \\
\text { Belief that waste segregation waste of money } \\
\text { Not recycle because recycling center far away }\end{array}$ \\
\hline Outcome factors & $\begin{array}{l}\text { PROENVI } \\
\text { REDLAND } \\
\text { NATRES } \\
\text { NOPOINT }\end{array}$ & $\begin{array}{l}\text { Recycling protect environment } \\
\text { Recycling reduces amount of waste to landfills } \\
\text { Waste segregation preserves natural resources } \\
\text { Belief that doing waste segregation for recycling is } \\
\text { no point }\end{array}$ \\
\hline Consequences & $\begin{array}{l}\text { ENERGY } \\
\text { SVMONEY } \\
\text { BETENVI }\end{array}$ & $\begin{array}{l}\text { Perception recycling save energy } \\
\text { Perception recycling save money } \\
\text { Perception recycling create better environment }\end{array}$ \\
\hline $\begin{array}{l}\text { Perceived lack of } \\
\text { facility }\end{array}$ & $\begin{array}{l}\text { NOTAVAIL } \\
\text { NOCOLL } \\
\text { AUTHORES }\end{array}$ & $\begin{array}{l}\text { Recycling facilities are not easily available. } \\
\text { No local collections for recycling } \\
\text { Responsibilities of local authority for waste } \\
\text { collections }\end{array}$ \\
\hline Moral norm & $\begin{array}{l}\text { GUILTY } \\
\text { AGAINST } \\
\text { SHARRES }\end{array}$ & $\begin{array}{l}\text { Feel that should not waste anything if it could be } \\
\text { used again } \\
\text { Feeling of guilt if did not do waste segregation } \\
\text { Feeling waste segregation goes against life } \\
\text { principles } \\
\text { Feeling that everybody should share responsible to } \\
\text { segregate waste. }\end{array}$ \\
\hline
\end{tabular}

There was no significant difference in terms of waste reduction between phase 1 and phase 2 of the program. However, a significant difference was detected between phase 1 and phase 3 (Table 5). This result indicates that the provision of food-waste bins together with recycling bins have reduced the volumes of waste disposed in landfill. 
Table 4: Volume of waste segregated by households before and after bins provision $(\mathrm{N}=69)$.

\begin{tabular}{lcccc}
\hline & $\begin{array}{c}\text { General Waste } \\
\mathrm{kg}(\%)\end{array}$ & $\begin{array}{c}\text { Recycle } \\
\text { waste kg }(\%)\end{array}$ & $\begin{array}{c}\text { Food waste } \\
\mathrm{kg}(\%)\end{array}$ & $\begin{array}{c}\text { Total waste } \\
\text { generated kg } \\
(\%)\end{array}$ \\
\hline Phase 1 & $974.3(100)$ & - & - & $974.28(100)$ \\
Phase 2 & $951.8(90.61)$ & $98.6(9.39)$ & - & $1050.4(100)$ \\
Phase 3 & $832.2(76.16)$ & $115.6(10.58)$ & $144.9(13.26)$ & $1092.7(100)$ \\
\hline Note: & $\begin{array}{l}\text { Phase 1 - No segregation } \\
\text { Phase 2 - Waste with segregation of general and recycled waste } \\
\text { Phase 3 - Waste with segregation of general, recycled and food waste }\end{array}$ \\
\hline
\end{tabular}

Table 5: Comparison in weight of general waste generated by households before and after the program $(\mathrm{N}=69)$.

\begin{tabular}{llllll}
\hline & Mean \pm SD & Median & IQR & t & $\boldsymbol{p}$-Value \\
\hline Before program (P1) & $14.12 \pm 5.39$ & 13.8 & 7.8 & 0.738 & 0.463 \\
After program (P2) & $13.79 \pm 5.17$ & 13.3 & 7.7 & & \\
\hline Before program (P1) & $14.12 \pm 5.39$ & 13.8 & 7.8 & 4.349 & 0.001 \\
After program (P3) & $12.06 \pm 4.68$ & 12.0 & 7.3 & & \\
\hline *Significant, $p<0.001$, T-test & & & & \\
\hline
\end{tabular}

\subsection{Behavioural changes of the community}

In the waste segregation program, nine behavioural factors show significantly positive changes from phase 1 to phase 3 (Table 6). In perceived behavioural control, the score for statement OPPORT (I have plenty of opportunities to do waste segregation) shows significant changes from phase 1 to phase 3 of the program. The households believed that opportunities for waste segregation increased after they have participated in the program. According to Knussen and Yule [9], people will not recycle if it is difficult for them, even if they feel that they have the ability to do so. Hence, this result supports the findings that there is a significant change in behaviour after the bin provision.

In terms of the situational factor, there are significant changes in the perception that waste segregation takes up too much time (TIME). Households did not agree that waste segregation took too much of their time after they had been provided with a recycling bin. According to Ho [11], this result indicates that with the available facilities and the collection services provided, less time was consumed to segregate waste.

Households show significant changes in behaviour for the outcome variable that waste segregation helps to protect the environment (PROENVI). These findings indicate that the awareness level of households have increased after the program. These changes resulted from the distribution of pamphlets regarding a household's recycling role in conserving the environment. Results of a study by 
DANIDA [12] in Malaysia showed that the level of environmental awareness and the interest from hawkers in the compost produced from the segregated food waste was increased after participating in a composting program. These findings suggest that an awareness program in this study causes a positive change of the household's behaviour.

All the consequent variables showed significant changes from phase 1 to phase 3 of the program. Households believed that segregating waste for recycling saves energy (ENERGY), saves money (MONEY) and creates a better environment for future generations (BETENVI). These changes appeared to be the consequences of distributing pamphlets, which educate households about recycling, which in turn promotes energy conservation and helps to protect the environment. This finding shows that the increases in awareness levels predict behavioural changes in households. Agamuthu et al.[13] suggests that an increase in awareness levels will increase the rate of recycling amongst the community.

For the perceived lack of facility, the statement, 'the local authority should responsible for waste collection' (AUTHORES), shows a positive change where the respondents agree that the local authority should provide them with such facilities. This result is supported by the study of Ho [11], who states that Singaporeans have the perception that recycling is the responsibility of the relevant authorities but not themselves. The Singapore government has started to realize that increasing recycling through the usual methods of legislation and enforcement will only produce short-term results [11]. The rate of recycling is increased after the involvement of the relevant authority. In this study, the involvement of the authority was demonstrated by the provision of the waste bins to the households.

In moral norm behaviour, there were significant changes to the scores on the statement 'I would feel guilty if I did not do waste segregation for my household waste' (GUILTY) and 'not doing waste segregation goes against my principles'

Table 6: Behavioural changes of communities towards the waste segregation program conducted.

\begin{tabular}{llcc}
\hline Components & Behavior factors & $\mathrm{F}$ & $p$-Value \\
\hline $\begin{array}{l}\text { Perceived behavioral } \\
\text { control }\end{array}$ & OPPORT & 23.46 & $0.001^{*}$ \\
\hline Situational factor & TIME & 19.66 & $0.001^{*}$ \\
\hline Outcome variables & PROENVI & 11.41 & $0.001^{*}$ \\
\hline $\begin{array}{l}\text { Consequence } \\
\text { variables }\end{array}$ & ENERGY & 6.500 & $0.039^{*}$ \\
& MONEY & 6.196 & $0.045^{*}$ \\
\hline $\begin{array}{l}\text { Perceived lack of } \\
\text { facility }\end{array}$ & AUTHORES & 6.080 & $0.048^{*}$ \\
\hline $\begin{array}{l}\text { Moral norm } \\
\text { behavior }\end{array}$ & GUILTY & 6.095 & $0.047^{*}$ \\
\hline
\end{tabular}

*Significant, $\mathrm{p}<0.05$ 
(AGAINST) from phase 1 to phase 2. Households agreed that they feel guilty if they are not participating in the waste segregation program, especially after the provision of the facilities. They also agreed that not performing waste segregation was against their principles.

\subsection{Principal component analysis factors affecting willingness participation}

In assessing the factors affecting the willingness of households to perform waste segregation activity, factor analysis with principal component analysis (PCA) was used with Varimax (orthogonal) rotation. The results of PCA of 24 items showed no problematic collinearity across dimensions. $\mathrm{KMO}=0.765$ showed a modest sampling adequacy of factor analysis (Table 7). The Bartlett's test is highly significant at the p-value equal to .00, approved that the PCA is applicable. The factor loadings demonstrated 6 dimensions; combined, this explained $66.51 \%$ of the total variances in the overall data.

According to the eigenvalue criterion, factors with eigenvalues greater than one are retained and factors with eigenvalues less than one are considered insignificant and therefore excluded. Table 8 reports the factors that influence the willingness of respondent's participation that explained $66.51 \%$ of the total variances in the overall data.

The dimensions of factor loadings were divided into 6 components where Factor 1 and Factor 2 explained the highest variance in the study, $30.24 \%$ and $10.56 \%$ respectively. The results of factor loadings are summarized in Table 8.

Factor 1 can be categorized as 'difficulty factors', where respondents are willing to participate more in the program if it is easy to them (as a pleasant activity), doesn't take up too much room and money and also if they have good collection services. Difficulty in performing waste segregation can be treated as inconvenience. Factor 2 was categorized as 'the environmental responsibility factors', as an increase in environmental awareness levels will encourage households to perform waste segregation. Factor 3 was categorized as 'the pleasure factor' where waste segregation was pleasing, favourable, has a satisfaction resource and was supported from somebody who explained the pleasure of households in carrying out waste segregation.

Factor 4 was categorized as the 'benefits gain factors'. Increased opportunities to recycle, to save money and energy were all benefits to the waste segregation program and had encouraged respondents to participate. Factor 5

Table 7: Total variance explained.

\begin{tabular}{llcl}
\hline Factor & Total & $\begin{array}{c}\text { Initial Eigenvalues } \\
\text { \% of variance }\end{array}$ & Cumulative \% \\
\hline 1 & 7.257 & 30.238 & 30.238 \\
2 & 2.534 & 10.556 & 40.795 \\
3 & 1.934 & 8.057 & 48.852 \\
4 & 1.838 & 7.659 & 56.510 \\
5 & 1.283 & 5.347 & 61.857 \\
6 & 1.115 & 4.644 & 66.501 \\
\hline
\end{tabular}


was categorized as the 'moral norm' where the moral norm relates to the individual's personal beliefs about the moral correctness or incorrectness of performing a specific behaviour [14]. Finally, Factor 6 represents the 'knowledge factors' where knowledge makes it easier for the activity to be performed. Gardner and Stern [15] argued that a lack of knowledge could be a serious barrier to action, however Ho [11] suggested that the ability to recycle is determined by the ability to acquire the skill to recycle through the possession of specific recycling knowledge.

Table 8: Factor loadings of PCA.

\begin{tabular}{|c|c|c|c|c|c|c|}
\hline & \multicolumn{6}{|c|}{ Factor } \\
\hline & 1 & 2 & 3 & 4 & 5 & 6 \\
\hline $\begin{array}{l}\text { Waste segregation programs are a waste of } \\
\text { money }\end{array}$ & .769 & & & & & \\
\hline Waste segregation takes up too much room & .737 & & & & & \\
\hline $\begin{array}{l}\text { I cannot see the point in waste segregation } \\
\text { for recycling }\end{array}$ & .725 & & & & & \\
\hline $\begin{array}{l}\text { I find the idea of waste segregation } \\
\text { unpleasant. }\end{array}$ & .630 & & & & & \\
\hline $\begin{array}{l}\text { I am not doing waste segregation because } \\
\text { there are no local collections }\end{array}$ & .620 & & & & & \\
\hline Waste segregation is too complicated & .599 & & & & & \\
\hline $\begin{array}{l}\text { Waste segregation for recycling helps to } \\
\text { protect the environment }\end{array}$ & & .825 & & & & \\
\hline $\begin{array}{l}\text { Waste segregation for recycling preserves } \\
\text { natural resources }\end{array}$ & & .777 & & & & \\
\hline $\begin{array}{l}\text { Everybody should share the responsibility to } \\
\text { segregate household waste }\end{array}$ & & .702 & & & & \\
\hline $\begin{array}{l}\text { Most of my family thinks that I should } \\
\text { segregate my waste. }\end{array}$ & & & .746 & & & \\
\hline $\begin{array}{l}\text { My feelings towards waste segregation are } \\
\text { favourable. }\end{array}$ & & & .739 & & & \\
\hline $\begin{array}{l}\text { The local council provides satisfactory } \\
\text { resources for waste segregation. }\end{array}$ & & & .651 & & & \\
\hline $\begin{array}{l}\text { I find the idea of waste segregation is } \\
\text { pleasing. }\end{array}$ & & & .586 & & & \\
\hline $\begin{array}{l}\text { I have plenty of opportunities to do waste } \\
\text { segregation. }\end{array}$ & & & & .751 & & \\
\hline $\begin{array}{l}\text { Waste segregation for recycling saves } \\
\text { energy }\end{array}$ & & & & .719 & & \\
\hline $\begin{array}{l}\text { Waste segregation for recycling saves } \\
\text { money }\end{array}$ & & & & .690 & & \\
\hline $\begin{array}{l}\text { Not do waste segregation goes against my } \\
\text { principles }\end{array}$ & & & & & .800 & \\
\hline $\begin{array}{l}\text { I feel I should not waste anything if it could } \\
\text { be used again }\end{array}$ & & & & & .667 & \\
\hline $\begin{array}{l}\text { I would feel guilty if I did not do waste } \\
\text { segregation for my household waste }\end{array}$ & & & & & .581 & \\
\hline $\begin{array}{l}\text { I know how to segregate my household } \\
\text { waste. }\end{array}$ & & & & & & .723 \\
\hline
\end{tabular}




\section{Conclusion}

The volume of waste that was segregated by the community was increased after the provision of recycling bins and food waste bins. An increase in the accessibility of recycling facilities has improved several waste segregation behaviours of a group or community living in Taman Sri Andalas. Several behaviours assessed in this study show significant improvement after the provision of recycling bins, food waste bins and recycled waste collection facilities.

\section{References}

[1] Sharifah Norkhadijah, S. I. \& Latifah, A. M., The challenge of future landfill: A case study of Malaysia. Journal of Toxicology and Environmental Health Sciences, 5(3), pp. 2400-2407, 2013.

[2] National Solid Waste Management Department (NSWMD). National Solid Waste Management Department, Malaysia. http:/www. kpkt.gov.my/jpspn_en_2013/main.php

[3] Chong, T., Newspaper article, 19 September 2012. Low rate in recycling, Utusan Malaysia.

[4] Ministry of Housing and Local Government (MHLG). http://www.kpkt.gov.my/

[5] Ajzen, I., The theory of planned behaviour. Organizational Behaviour and Human Decision Processes, 50(2), pp. 179-211, 1991.

[6] Tang, Z., Chen, X., \& Luo, J., Determining socio-psychological drivers for rural household recycling behaviour in developing countries: A case study from Wugan, Hunan China. Environment and Behaviour, 2010.

[7] Ramayah, T., Lee, J. W. C., \& Lim, S., Sustaining the environment through recycling: An empirical study. Journal of Environmental Management, 102, 141-147, 2012.

[8] Chen, M. F., \& Tung, P. J., The Moderating Effects Of Perceived Lack Of Facilities And Implementation Performance Of Policies On Consumers' Recycling Intentions. Environment and Behaviour, 2009.

[9] Knussen, C., \& Yule, F., I'm not in the habit of recycling: The role of habitual behaviour in the disposal of household waste. Environment and Behaviour, 40, 683-702. 2008.

[10] Cotterill, F. P. D., Al-Rasheid, K. A. S., \& Foissner, W., Conservation of protists: is it needed at all? Biodiversity Conservation 17, pp. 427-44, 2008.

[11] Ho., Y. Y., Phd Thesis, Recycling as a sustainable waste management strategy for Singapore: An investigation to find ways to promote Singaporeans Household waste recycling behaviour. Lund University. 2002.

[12] Danish International Development Assistance (DANIDA). Solid waste management component. http://www.ecoideal.com.my 
148 Waste Management and The Environment VII

[13] Agamuthu, P., Santha, C., Fauziah, S. H., \& Dennis, V., Phd thesis. Related policies for sustainable waste management in Malaysia, http://umconference.um.edu.my, 2010.

[14] Tonglet, M., Phillips, P. S. \& Read, A. D., Using the theory of planned behaviour to investigate the determinants of recycling behaviour, a case study from Brixworth, UK. Resources, conservation and recycling, 41, pp.191-214, 2004.

[15] Gardner, G. T., \& Stern, P. C. Environmental problems and human behaviour. Boston: Allyn and Bacon, pp. 23-45, 1996. 